\title{
Ribosomal RNA Genes Challenge the Monophyly of the Hyalospheniidae (Amoebozoa: Arcellinida)
}

\author{
Enrique Lara ${ }^{a, b, c, e}$, Thierry J. Heger ${ }^{b, c}$, Flemming Ekelund ${ }^{a}$, \\ Mariusz Lamentowicz ${ }^{\mathrm{d}}$, and Edward A.D. Mitchell ${ }^{\mathrm{b}, \mathrm{c}, 1}$
}

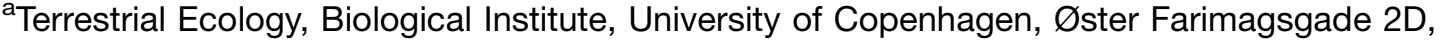
DK-1353 Copenhagen K, Denmark

bWSL, Swiss Federal Institute for Forest, Snow and Landscape Research, Ecosystem Boundaries Research Unit, Wetlands Research Group, Station 2, CH-1015 Lausanne, Switzerland

'École Polytechnique Fédérale de Lausanne (EPFL), Laboratory of Ecological Systems, Station 2, $\mathrm{CH}-1015$ Lausanne, Switzerland

${ }^{\mathrm{d}}$ Department of Biogeography and Palaeoecology, Faculty of Geosciences, Adam Mickiewicz University in Poznań, Dziegielowa 27, 61-680 Poznań, Poland

eUnité d'Ecologie, Systématique et Evolution-CNRS UMR8079 Université Paris-Sud 11, bâtiment 360, 91405 Orsay Cedex, France
}

Submitted February 20, 2007; Accepted September 1, 2007

Monitoring Editor: Hervé Philippe

To date only five partial and two complete SSU rRNA gene sequences are available for the lobose testate amoebae (Arcellinida). Consequently, the phylogenetic relationships among taxa and the definition of species are still largely dependant on morphological characters of uncertain value, which causes confusion in the phylogeny, taxonomy and the debate on cosmopolitanism of free-living protists. Here we present a SSU rRNA-based phylogeny of the Hyalospheniidae including the most common species. Similar to the filose testate amoebae of the order Euglyphida the most basal clades have a terminal aperture; the ventral position of the pseudostome appears to be a derived character. Family Hyalospheniidae appears paraphyletic and is separated into three clades: (1) Heleopera sphagni, (2) Heleopera rosea and Argynnia dentistoma and (3) the rest of the species from genera Apodera, Hyalosphenia, Porosia and Nebela. Our data support the validity of morphological characters used to define species among the Hyalospheniidae and even suggest that taxa described as varieties may deserve the rank of species (e.g. N. penardiana var. minor). Finally our results suggest that the genera Hyalosphenia and Nebela are paraphyletic, and that Porosia bigibbosa branches inside the main Nebela clade.

(c) 2007 Elsevier GmbH. All rights reserved.

Key words: Amoebozoa; Arcellinida; biogeography; phylogeny; SSUrRNA gene; testate amoebae.

\footnotetext{
Corresponding author; WSL, Swiss Federal Institute for Forest, Snow and Landscape Research, Ecosystem Boundaries Research Unit, Wetlands Research Group, Station 2, $\mathrm{CH}-1015$ Lausanne, Switzerland, fax +41216933913

e-mail edward.mitchell@wsl.ch (E.A.D. Mitchell).
}

\section{Introduction}

The testate lobose amoebae (Arcellinida Kent, 1880) make up a group of protozoa present worldwide mostly in freshwater and mosses, with some representatives also inhabiting soils and even marine habitats. The recent finding of some 
vase-shaped microfossils possibly belonging to the Arcellinida (Porter et al. 2003) has invested this group with a particular importance: these fossils are generally considered as the oldest undisputable eukaryotic remains ever found, putting Arcellinida in a central position in dating the apparition of life on earth (Berney and Pawlowski 2006). However, in spite of their importance, the phylogenetic position of the Arcellinida within the tree of life has remained unresolved for a long time and their taxonomy still remains unsatisfactory. The Arcellinida have recently been shown to belong to the Amoebozoa as a sister-group to the lobose naked amoebae families Amoebidae and Hartmannellidae (Nikolaev et al. 2005). The seven taxa analysed by these authors suggested that the Arcellinida are monophyletic.

The family Hyalospheniidae Schultze 1877 includes some of the most common, conspicuous, and well-studied lobose testate amoebae. Members of this family are especially abundant and diverse in oligotrophic wetland such as Sphagnum peatlands but some can also be found in other mosses, freshwater habitats, and soils (Mitchell et al. 1999, 2000). It was suggested that the 750 Mya old vase-shaped microfossils belonged to this family (Porter and Knoll 2000; Porter et al. 2003). Several species have been claimed to have a limited geographic distribution, the most famous case being certainly Apodera vas (Deflandre 1936; Van Oye 1944). This and other species of the Apodera genus have not been recorded in the extra-tropical northern Hemisphere where most studies on the ecology and taxonomy of testate amoebae took place (Mitchell and Meisterfeld 2005). Members of the family Hyalospheniidae sensu Schultze 1877 are characterized by an ovoid or pyriform shell, which is laterally compressed. The shell may be composed solely of proteinaceous material (genus Hyalosphenia) or of siliceous shell plates recycled from other testate amoebae such as Euglypha, sometimes with agglutinated mineral particles (Meisterfeld 2000). Some species, like Heleopera sphagni and Hyalosphenia papilio host photosynthetic endosymbionts and are thus mixotrophic (Penard 1902).

The classification of the Hyalospheniidae sensu Schultze 1877 is based on characters of the test such as composition (proteinaceous or agglutinated), shape of the aperture (circular, oval or almost linear) and shape of the shell. Jung (1942) split the very large and widespread genus Nebela into twelve genera. Meisterfeld (2000) recognizes four families within the Hyalospheniidae sensu Schultze 1877: Nebelidae (restricted only to the taxa which formerly were included in the genus Nebela), Hyalospheniidae sensu stricto, Lesquereusiidae and Heleoperidae. To date, however, the existing morphological and molecular data has not allowed validation of this classification. In this study, we therefore aimed to provide new molecular data on some representative genera and species of Hyalospheniidae sensu Schultze 1877 in order to clarify the phylogenetic position of the main morphological types.

Testate amoebae, in general, and the Arcellinida in particular, are increasingly used in ecology and palaeoecology with applications in the reconstruction of past climatic fluctuations over the Holocene (Charman 2001). However, both the phylogeny and taxonomy of this group urgently needs to be updated (Mitchell et al. in press). It has been shown that, for bioindication purposes, the highest possible taxonomic resolution should be attained to maximize the ecological indicator value of the assemblages, recorded (Bobrov et al. 2002). Clearly, with a more reliable taxonomy the value of this group of organisms for ecologists and palaeoecologists would be even higher. Thus our broader goal is both to increase the knowledge on the phylogeny and taxonomy of this group and to improve its value for other fields of research.

\section{Results}

We obtained a total of 16 SSU rRNA gene sequences from 14 different taxa (Figs 1 and 2), which included representatives from three of the four families proposed by Meisterfeld (2000), and inferred their phylogenetic relationships based on likelihood and Bayesian analyses.

\section{Structure of the SSU rDNA Gene of the Hyalospheniidae}

We found a class I intron of approximately 450 base pairs starting at position 1200 on the SSU rDNA gene of Schizosaccharomyces pombe (accession file X58056 in GenBank) in seven taxa: $N$. carinata, $N$. tincta var. tincta, $N$. tincta var. major (isolate from Sweden only), Porosia bigibbosa, Nebela tubulosa, Hyalosphenia papilio and Heleopera rosea. This intron has been also found in myxomycetes like Fuligo septica (Fiore-Donno et al. 2005) and corresponds to position S956 according to the nomenclature by Johansen and Haugen (2001). 




Figure 1. Illustrations of the sequenced Arcellinida taxa. The illustrated individuals correspond to the sequenced individuals with three exceptions for which no illustrations were available: (a) Argynnia dentistoma (from Grindelwald $\mathrm{CH}$ and not from Modrava CZ), (b) Heleopera rosea (from Sweden and not from La Chaux d'Abel bog CH), (c) Nebela lageniformis, (d) Apodera vas, (e) Hyalosphenia elegans, (f) H. papilio, (g) Porosia bigibbosa, (h) N. carinata, (i \& j) N. penardiana var. minor, (k) N. penardiana (from Chlebowo mire PL and not from Grindelwald, CH), (l) N. tubulosa, (m) N. tincta var. major from Ireland, (n) N. tincta var. major from Sweden, (o) $N$. tincta, (p) $N$. flabellulum. Scale bars $=50 \mu \mathrm{m}$, except for $N$. penardiana var. minor and H. elegans: Scale bar $=20 \mu \mathrm{m}$. 


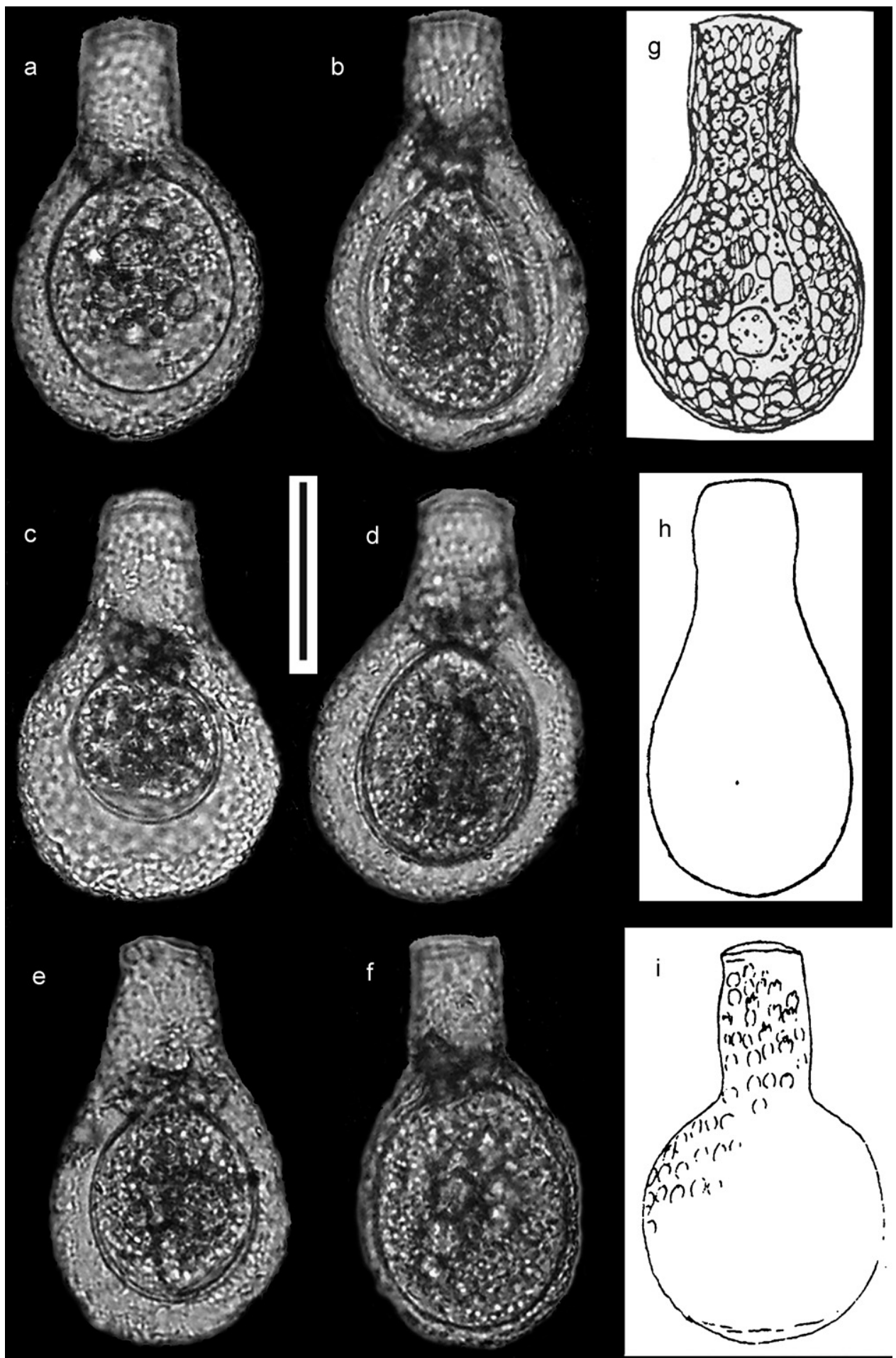

Figure 2. Morphological variation within the studied population of Nebela lageniformis from Peru (a-f; scale bar $=50 \mu \mathrm{m}$ ). The original drawings from the descriptions of Nebela lageniformis ( $\mathrm{g}$, after Penard 1902 and $\mathrm{h}$, after Deflandre 1936) and Nebela lageniformis var. cordiformis (i, after Heinis 1914) are given for comparison (original drawings lacked scale). 


\section{Phylogenetic Position of the Studied Species}

For each phylogenetic analysis achieved in this work, maximum likelihood and Bayesian methods of tree building gave exactly the same topology. Figure 3 shows the position of the studied taxa in the phylogenetic tree of the Amoebozoa (selected closely related naked amoebae). This tree illustrates the paraphyly of Hyalospheniidae sensu lato. Heleopera sphagni branched at the base of the whole arcellinid clade, while Heleopera rosea and Argynnia dentistoma formed another group (maximum likelihood bootstrap $=87$; Bayesian analysis posterior probabilities $=0.63$ ) at the base of a clade formed by species with a ventral pseudostome (Bullinularia indica, Trigonopyxis arcula, Arcella artocrea and Centropyxis laevigata) and the rest of the Hyalospheniidae. Inside this group, $N$. lageniformis and Apodera vas, were the most basal species. We observed a continuum of test shapes between typical $N$. lageniformis and N. I. var. cordiformis (Fig. 2) in our studied population that suggested the possible existence of more than one taxon. However, sequencing of the whole sample provided only one single sequence, and the cloning of PCR products yielded only one type of clone. Besides these species, all other members of genera Nebela and Hyalosphenia branched together in a robust clade (100/1.00), hereafter referred to as "core Nebelas".

To improve resolution, we restrict our analysis to short branch Hyalospheniidae, allowing us to use 830 positions instead of 450 . This analysis (Fig. 4) confirms the existence of a clade constituted (for now) of two closely related species, Apodera vas and Nebela lageniformis which branch

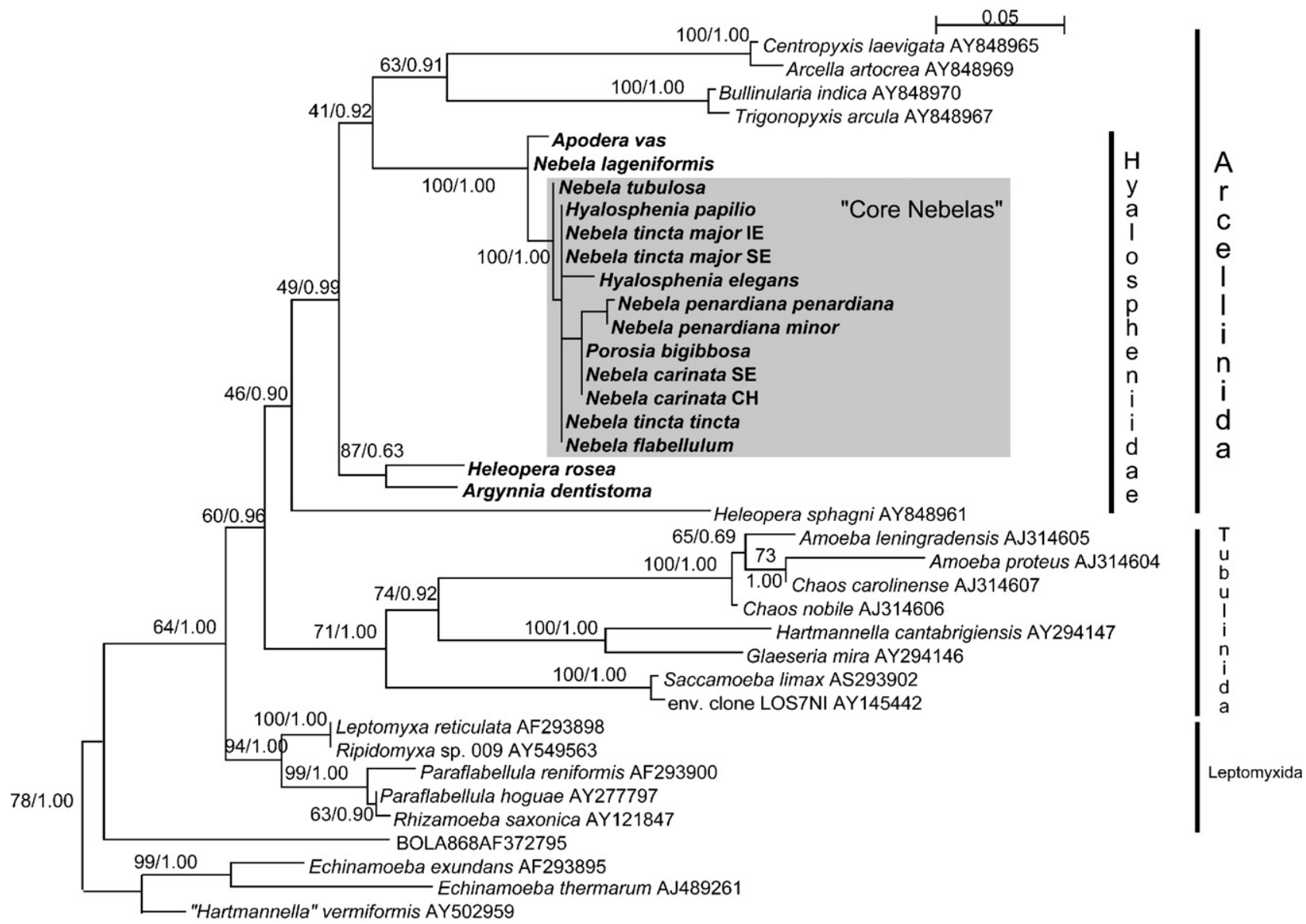

Figure 3. Maximum likelihood bootstrap consensus tree (GTR model, 450 sites) of the Arcellinida and related taxa among the Tubulina illustrating the paraphyly of the Hyalospheniidae. Species names in bold represent new sequences. The numbers along the branches represent the bootstraps obtained by the maximum likelihood method and the posterior probabilities obtained by Bayesian analysis. 




Figure 4. Maximum likelihood bootstrap consensus tree (GTR model, 830 sites) of the relatively short branch forming Arcellinida (i.e. excluding Centropyxis laevigata and Heleopera sphagni), illustrating the relatedness of Nebela lageniformis and Apodera vas forming an independent clade separated from the core Nebelas. Species names in bold represent new sequences. The numbers along the branches represent the bootstraps obtained by the maximum likelihood method and the posterior probabilities obtained by Bayesian analysis.

together, with a good support mostly from maximum likelihood analysis (77/0.70).

The phylogeny of the core Nebelas is detailled in Figure 5. The species Apodera vas and Nebela lageniformis were used as outgroups in this analysis. At the base of the clade, Hyalosphenia elegans formed a rather long branch, and did not group with its congeneric $H$. papilio. Instead, the latter was linked, in a basal position, to other representatives of genus Nebela (83/0.76). The apparent paraphyly of genus Hyalosphenia might be due to a long-branch artefact phenomenon caused by the sequence of Hyalosphenia elegans.

Inside this clade, the taxa $P$. bigibbosa, Nebela carinata, $N$. penardiana var. penardiana and $N$. penardiana var. minor are grouped together (57/1.00). The two varieties of $N$. penardiana branched together indeed with strong support (99/1.00), but were nevertheless genetically quite distinct $(10 \%$ of sequence difference on the studied fragment). The taxa $N$. tincta var. tincta, $N$. tincta var. major and $N$. flabellulum branched together robustly $(95 / 0.83)$, and their sequences were very similar ( $<1 \%$ of sequence difference on the studied fragment). $N$. tubulosa branched with this latter group in the two tree construction methods; however, its position in the tree was highly unstable, the support of this branch being very low (bootstrap value/posterior probability $<50 / 0.5)$.

It is noteworthy that the sequences obtained from different samples, from different geographic origins, from the same species were identical. Also, our sequences from Nebela tincta major and Hyalosphenia papilio were identical to the shorter sequences presented by Nikolaev et al. (2005), available in Genbank under the accession files AY848968 and AY848966, respectively. These sequences were not included in the analysis, for they are shorter than the sequences studied here.

\section{Discussion}

\section{Structure of the Fragment of the Studied SSU rRNA Gene}

The presence of a class I intron in the SSU rRNA gene of the some of the studied species, which 


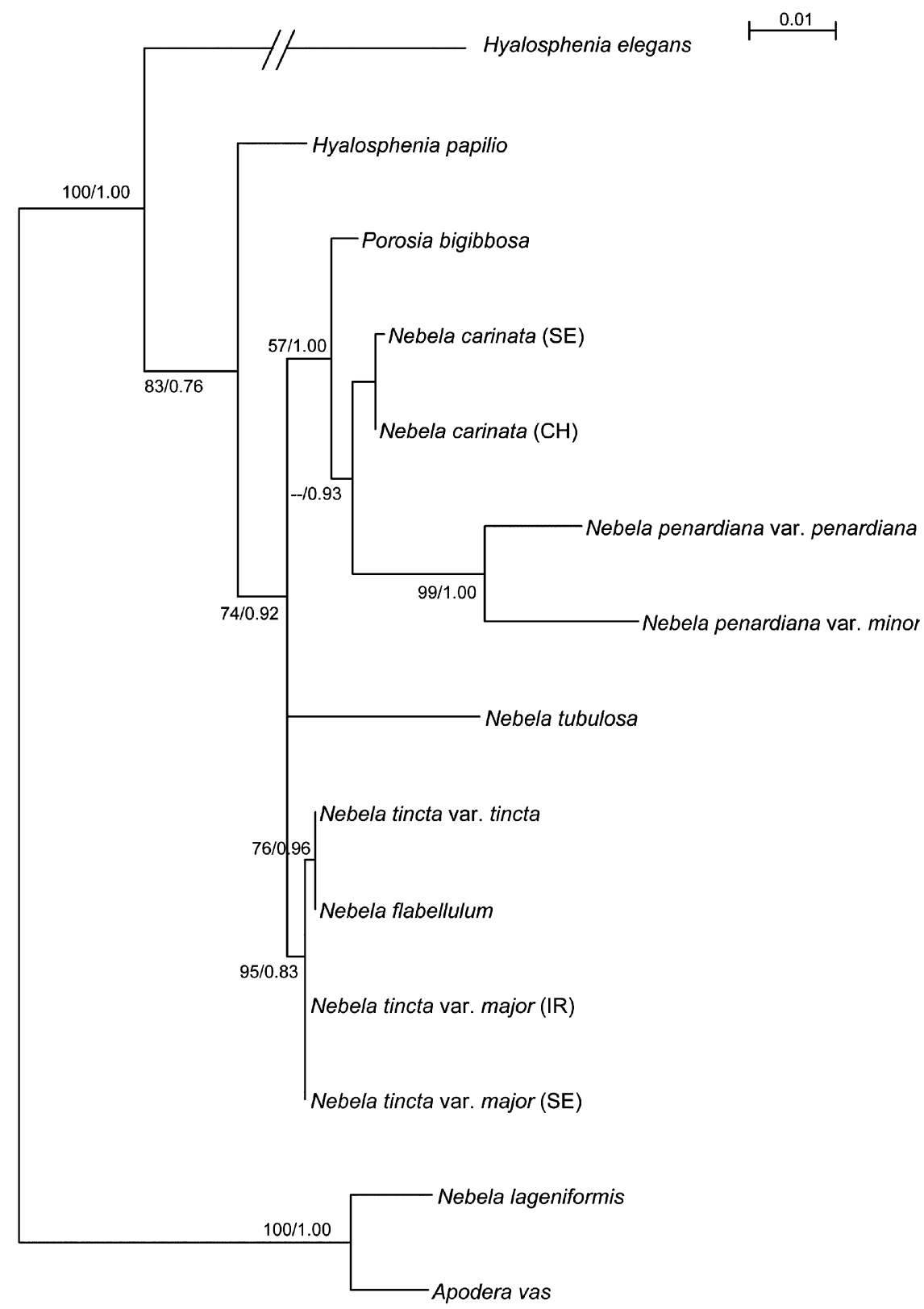

Figure 5. Maximum likelihood bootstrap consensus tree (GTR model, 948 sites) of the core Nebelas. Numbers at the nodes represent successively bootstrap values obtained by maximum likelihood and posterior probabilities obtained by Bayesian analysis. Only bootstrap values above 50 are represented. The branch of Hyalosphenia elegans is reduced from half of its size for clarity.

was also present in three of the seven taxa studied by Nikolaev et al. (2005), is remarkable, but the pattern of presence and absence of this intron does not seem to have any phylogenetical significance. Indeed, it is present in the basal branching Heleopera rosea, but is absent in, for instance, both varieties of Nebela penardiana.
Nikolaev et al. (2005) did not find it in their sequence from $N$. tincta var major, and we did not find it either in the sequence of our isolate of this taxon from Ireland, although it was present in our sequence from Sweden. The inconstant presence of such an intron in the SSU rRNA gene in a given taxon has been already documented in 
another amoebozoan, the mycetozoan Fuligo septica (Fiore-Donno et al. 2005).

\section{Phylogenetic Position of the Studied Species}

Based on the available sequence including the 16 new ones presented here the Arcellinida remain monophyletic. However, molecular data is still missing from several important taxa (e.g. Cryptodifflugia, Phryganella, etc.). Our results suggest that a ventral position of the pseudostome is most probably a derived character amongst the Arcellinida. The most basal clades (Heleopera sphagni and $H$. rosea/Argynnia dentistoma) have an acrostome opening, like the more derived core Nebelas. This situation is similar to the one observed in the Euglyphida, where ventral opened pseudostomes like observed in Trinematidae derived from acrostome forms such as Euglyphidae and Assulinidae (Lara et al. 2007).

Molecular data can be useful to assess the phylogenetic value of various morphological criteria used in taxonomy. Our results show that the presence of foreign particles in the test is not necessarily a reliable criterion for phylogenetic relationships. For example, Hyalosphenia papilio as well as $H$. elegans lack foreign material. Still, according to our analysis $H$. papilio is more closely related to the large Nebela spp., to which it resembles both in shape and size, than to $H$. elegans. However, as long branches had an effect on the tree topology this result should be confirmed by further analyses on more taxa. Nevertheless, test composition sometimes correlates with molecular phylogeny, e.g. Argynnia dentistoma, which was initially included in the genus Nebela, differs from Nebela s.str. by the porous cement agglutinating the (rough) particles that compose the test (Jung 1942; Vucetich 1974). In accordance with this, molecular phylogeny suggests that Argynnia is only distantly related to members of genus Nebela. Conversely, a synapomorphy of Nebela s.l. appears to be a test built from an organic amorphous matrix in which prey material (mainly from euglyphid amoebae) may be included. Interestingly, in the absence of preys, some species like $N$. collaris are able to form entirely organic tests (MacKinlay 1936). The fact of having a test without xenosome is therefore not a sufficient criterion for defining the genus Hyalosphenia.

Morphologically, the genus Heleopera is well defined by its slit-like terminal positioned pseudostome, which is generally considered to be an apomorphic character. However, our molecular data suggest that genus Heleopera is paraphyletic (Fig. 3). This result should be mitigated by the fact that the long branch formed by $H$. sphagni certainly has an effect on tree topology. The numerous insertions in its SSU rRNA gene sequence favour that $H$. sphagni is a fast-evolving taxon. Here again, more data are needed to ascertain whether genus Heleopera is actually paraphyletic or not.

Inside the core Nebelas, an important criterion for deep phylogenetic relationships seems to be the general shape of the shell.

The two species with an elongated tubular neck, Apodera vas and Nebela lageniformis branch together at the base of the "core Nebelas" clade, and their relatedness is relatively well-supported, mostly with the ML analysis (77/0.70). The main morphological difference between these two taxa (besides the size) is the presence of a constricted neck in $A$. vas. Hyalosphenia elegans, with its long neck and characteristic test with many small depressions also branches alone. It should be noted that, based on its morphology, the "variety" of $N$. lageniformis studied here (Fig. 2) could possibly be assigned to $N$. I. var. cordiformis (Heinis 1914). This taxon is wider than the type. However, in our sample from Peru, we observed a continuum of test shapes between typical $N$. lageniformis and N. I. var. cordiformis (see Fig. 2), but we obtained only one single sequence and only one type of clone from this population. Until the taxonomic relationships between these two taxa are better understood through a combined morphological and molecular study, we prefer to adopt a conservative position and consider that $N$. I. var. cordiformis is the product of the phenotypic plasticity of $N$. lageniformis, and that these two forms are not separated genetically. It would however not be impossible that further work may show that, contrary to this conservative view, the different varieties of Nebela lageniformis are genetically distinct, as we report here for the varieties of Nebela tincta and $N$. penardiana (see further).

It should be noted that $A$. vas is one of the "flagship species" of microorganisms with a limited distribution while $N$. lageniformis is considered to be cosmopolitain (Mitchell and Meisterfeld 2005). The two taxa differ only in 3\% in the portion of the SSU rRNA gene examined here but they nevertheless are certainly different from each other both from the genetic and the morphological points of view. Smith and Wilkinson 
(1987) suggested that cosmopolitan species evolved prior to the break-up of the super continent of Pangea, while the taxa specific to the southern hemisphere has evolved during the Jurassic era in Gondwanaland. Although the lack of a reliable fossil record makes it impossible to date the separation between $A$. vas and $N$. lageniformis, we believe that this event is more recent than the separation of Laurasia and Gondwana because of (1) their similar morphology and SSU rRNA gene sequence and (2) the putative extremely long evolutionary history of the Arcellinida (Porter et al. 2003). As Apodera vas has not yet been recorded in North America or in Eurasia where most of the studies on testate amoebae have been done, it can be assumed that it evolved somewhere in the former Gondwana, and has still not reached similar habitats in the northern continents.

The rest of the studied species, referred to as "core Nebelas" clustered together with a strong support. These species all had a shorter neck or a test generally tapering from the broadest part to the pseudostome. At the base of this clade, the mixotrophic Hyalosphenia papilio branches with a moderate support; notably, it is the only species in the "core Nebelas" investigated in this study never to incorporate xenosomes (mineral elements from external origin). Possibly this more transparent (but amber coloured) shell allows more light to reach its photosynthetic endosymbionts.

Besides $H$. papilio, all members of this clade belong to genus Nebela, with the exception of Porosia bigibbosa. Porosia was suggested by Jung (1942), to include forms with two invaginated pores on the test. The ecology of $P$. bigibbosa differs greatly from the other studied members of the Nebela s.l. genus, being abundant in forest litter and rare or exceptional in mosses and Sphagnum (Todorov 2002). In spite of these morphological and ecological differences, its phylogenetic position does not support its classification inside the monotypic genus Porosia.

The two varieties of Nebela penardiana studied here robustly cluster together with high statistical support; however, they appear distantly related in the tree. Morphologically, they can be easily differentiated; besides the size difference, the nominal variety being more pear-shaped than N. p. var. minor. In addition, it seems that the minor variety is restricted to tropical regions, where it can be relatively abundant (GauthierLièvre 1957). Based on our results, it might seem adequate to give the specific status to this variety.
However, we feel that more data would be required to revise the taxonomy.

Nebela tincta var. tincta, $N$. tincta var. major, and $N$. flabellulum make up a very distinctive clade. Some of these relatively smaller and rounded forms are not restricted to the wet and acidic Sphagnum environment. Genetic data suggest that the three taxa presented here are very closely related. Interestingly, while the first two taxa are considered as subspecies of $N$. tincta, and are included in the " $N$. tincta major-bohemica-collaris species complex" (Charman et al. 2000; Warner 1987), previous studies did not relate $N$. flabellulum to this group. Our molecular data further suggests that $N$. tincta tincta is even more closely related to $N$. flabellulum than it is to $N$. tincta major (76/0.96). While the two subspecies of $N$. tincta share an identical morphology and are differentiated only by size, $N$. tincta tincta and $N$. flabellulum have the same cell length, but clearly differ in width, the latter having a much broader test and almost no neck (Fig. 1, Table 1).

\section{Methods}

Origin of the samples, identification: A total of fourteen species and subspecies were obtained from Sphagnum, other mosses, and forest litter collected from a broad range of sampling locations (Table 1, Figs 1 and 2). Two species, Nebela carinata and $N$. tincta major, were isolated from two different locations, as a very first step towards a study of their geographical variability. The amoebae were extracted from the mosses by sieving and back sieving using appropriate mesh sizes $(300 \mu \mathrm{m}$ down to $10 \mu \mathrm{m})$, picked individually with a narrow diameter pipette under the dissecting or inverted microscope and isolated for DNA extraction.

Scanning electron microscopy imaging: For SEM observations, the tests were rinsed with demineralized water and then kept during 1 week in a desiccator. The samples were coated with gold in a Bal-Tec SCD005 sputter, or in a Jeol 4x. Samples were observed either with a PHILIPS XL30 FEG microscope at a tension of $5 \mathrm{kV}$ or with a Jeol $840 \mathrm{a}$ at a tension $20 \mathrm{kV}$.

Nucleic acids extraction and amplification: DNA was extracted using a guanidine thiocyanate protocol (Chomczynski and Sacchi 1987). Partial SSU sequences were obtained by PCR. DNA was amplified with the universal eukaryotic primers EUK516F (GGAGGGCAAGTCTGGT) and EUK1643R (GACGGGCGGTGTGTACA), in a total volume of $25 \mu \mathrm{l}$ with an amplification profile consisting in a 35 cycles program of $1 \mathrm{~min}$ at $94^{\circ} \mathrm{C}, 1 \mathrm{~min}$ at $50^{\circ} \mathrm{C}$ and $1 \mathrm{~min} 30$ at $72{ }^{\circ} \mathrm{C}$ with a final elongation of $10 \mathrm{~min}$ at $72^{\circ} \mathrm{C}$. The PCR mix contained 5\% DMSO and $10 \mu \mathrm{M}$ TMA. Afterwards, a seminested protocol was used to obtain specific amplification of testate amoebae DNA, using the following primers in combination with the universal primers: Arcell1F (GAAAGTGGTGCATGGCCGTTT) with EUK1643R and Hyalo2R (GCATTTCATTGTAACGCGC) with EUK516. In both cases, PCR products from the first amplification were diluted 250 times and used as a template for the second amplification. 
Table 1. List of sequenced taxa sampling location and morphometric measurements.

\begin{tabular}{|c|c|c|c|c|c|c|}
\hline \multirow[t]{2}{*}{ Taxon } & \multirow[t]{2}{*}{ Sampling location } & \multirow[t]{2}{*}{ Co-ordinates } & & \multirow{2}{*}{$\begin{array}{l}\text { Altitude } \\
(\mathrm{m})\end{array}$} & \multicolumn{2}{|c|}{ Shell dimensions* } \\
\hline & & & & & Length $(\mu \mathrm{m})$ & Breadth $(\mu \mathrm{m})$ \\
\hline Apodera vas & $\begin{array}{l}\text { Wet moss from } \\
\text { Blepharidophyllum- } \\
\text { dominated Mire, Marion } \\
\text { Island (ZA) }\end{array}$ & $46^{\circ} 53^{\prime} \mathrm{S}$ & $37^{\circ} 51^{\prime} \mathrm{E}$ & 27 & $162 \pm 4$ & $85 \pm 2$ \\
\hline $\begin{array}{l}\text { Argynnia } \\
\text { dentistoma }\end{array}$ & $\begin{array}{l}\text { Poor fen with Molinia, } \\
\text { Modrava, (CZ) }\end{array}$ & $49^{\circ} 01^{\prime} \mathrm{N}$ & $13^{\circ} 26^{\prime} \mathrm{E}$ & 980 & $96 \pm 3$ & $64 \pm 1$ \\
\hline Helopera rosea & $\begin{array}{l}\text { Sphagnum, La Chaux } \\
\text { d'Abel Peatland (CH) }\end{array}$ & $47^{\circ} 10^{\prime} \mathrm{N}$ & $06^{\circ} 56^{\prime} \mathrm{E}$ & 1006 & $107 \pm 2$ & $77 \pm 2$ \\
\hline $\begin{array}{l}\text { Hyalosphenia } \\
\text { elegans }\end{array}$ & $\begin{array}{l}\text { Sphagnum, Cachot } \\
\text { Peatland (CH) }\end{array}$ & $47^{\circ} 50^{\prime} \mathrm{N}$ & $06^{\circ} 40^{\prime} \mathrm{E}$ & 1050 & $99 \pm 6$ & $51 \pm 4$ \\
\hline $\begin{array}{l}\text { Hyalosphenia } \\
\text { papilio }\end{array}$ & $\begin{array}{l}\text { Sphagnum, } \\
\text { Ryggmossen Peatland } \\
\text { (SE) }\end{array}$ & $60^{\circ} 00^{\prime} \mathrm{N}$ & $17^{\circ} 15^{\prime} \mathrm{E}$ & 58 & $123 \pm 9$ & $75 \pm 17$ \\
\hline Nebela carinata & $\begin{array}{l}\text { Sphagnum, Bog pool, } \\
\text { Ryggmossen Peatland } \\
\text { (SE) }\end{array}$ & $60^{\circ} 00^{\prime} \mathrm{N}$ & $17^{\circ} 15^{\prime} \mathrm{E}$ & 58 & $177 \pm 7$ & $124 \pm 7$ \\
\hline Nebela carinata & $\begin{array}{l}\text { Sphagnum, Praz-Rodet } \\
\text { Bog, (CH) }\end{array}$ & $46^{\circ} 33^{\prime} \mathrm{N}$ & $06^{\circ} 10^{\prime} \mathrm{E}$ & 1041 & $179 \pm 10$ & $129 \pm 5$ \\
\hline Nebela flabellulum & $\begin{array}{l}\text { Sphagnum, Pitsligo } \\
\text { bog, Scotland (GB) }\end{array}$ & $57^{\circ} 36^{\prime} \mathrm{N}$ & $02^{\circ} 09^{\prime} \mathrm{W}$ & 110 & $78 \pm 4$ & $88 \pm 2$ \\
\hline $\begin{array}{l}\text { Nebela } \\
\text { lageniformis }\end{array}$ & $\begin{array}{l}\text { Moss, summit of } \\
\text { Huayna Pichu (PE) }\end{array}$ & $13^{\circ} 09^{\prime} \mathrm{S}$ & $72^{\circ} 32^{\prime} W$ & 2300 & $116 \pm 5$ & $68 \pm 4$ \\
\hline $\begin{array}{l}\text { Nebela penardiana } \\
\text { var. penardiana }\end{array}$ & $\begin{array}{l}\text { Brown moss, Alpine } \\
\text { Rich Fen, Grindelwald } \\
\text { (CH) }\end{array}$ & $46^{\circ} 40^{\prime} \mathrm{N}$ & $08^{\circ} 01^{\prime} \mathrm{E}$ & 2343 & $144 \pm 8$ & $124 \pm 5$ \\
\hline $\begin{array}{l}\text { Nebela penardiana } \\
\text { var. minor }\end{array}$ & $\begin{array}{l}\text { Moss, rainforest near } \\
\text { Volcán Arenal (CR) }\end{array}$ & $10^{\circ} 28^{\prime} \mathrm{N}$ & $84^{\circ} 15^{\prime} \mathrm{W}$ & 1000 & $81 \pm 4$ & $41 \pm 3$ \\
\hline $\begin{array}{l}\text { Nebela tincta var. } \\
\text { major }\end{array}$ & $\begin{array}{l}\text { Sphagnum, Poor Fen } \\
\text { "Scragh Bog" (IE) }\end{array}$ & $53^{\circ} 35^{\prime} \mathrm{N}$ & $07^{\circ} 22^{\prime} \mathrm{W}$ & 98 & $117 \pm 5$ & $82 \pm 4$ \\
\hline $\begin{array}{l}\text { Nebela tincta var. } \\
\text { major }\end{array}$ & $\begin{array}{l}\text { Sphagnum, } \\
\text { Ryggmossen Peatland } \\
\text { (SE) }\end{array}$ & $60^{\circ} 00^{\prime} \mathrm{N}$ & $17^{\circ} 15^{\prime} \mathrm{E}$ & 58 & $118 \pm 5$ & $82 \pm 3$ \\
\hline $\begin{array}{l}\text { Nebela tincta var. } \\
\text { tincta }\end{array}$ & $\begin{array}{l}\text { Sphagnum, } \\
\text { Ryggmossen Peatland } \\
\text { (SE) }\end{array}$ & $60^{\circ} 00^{\prime} \mathrm{N}$ & $17^{\circ} 15^{\prime} \mathrm{E}$ & 58 & $81 \pm 4$ & $124 \pm 5$ \\
\hline Nebela tubulosa & $\begin{array}{l}\text { Sphagnum, Poor Fen, } \\
\text { Granges-Narboz (FR) }\end{array}$ & $46^{\circ} 52^{\prime} \mathrm{N}$ & $06^{\circ} 16^{\prime} \mathrm{E}$ & 823 & $\begin{array}{l}215 \pm 13 \\
(N=3)\end{array}$ & $\begin{array}{l}120 \pm 17 \\
(N=3)\end{array}$ \\
\hline Porosia bigibbosa & $\begin{array}{l}\text { Forest litter under Picea } \\
\text { abies, near Marchairuz } \\
\text { Pass (CH) }\end{array}$ & $46^{\circ} 33^{\prime} \mathrm{N}$ & $06^{\circ} 15^{\prime} \mathrm{E}$ & 1300 & $154 \pm 4$ & $99 \pm 5$ \\
\hline
\end{tabular}

*Average and standard deviation. $\mathrm{N}=10$, unless otherwise stated.

For the first pair of primers, a first denaturation step of $5 \mathrm{~min}$ was applied, followed by a 30 cycles program consisting of $1 \mathrm{~min}$ at $94^{\circ} \mathrm{C}, 1 \mathrm{~min}$ at $60^{\circ} \mathrm{C}$ and $1 \mathrm{~min}$ at $72^{\circ} \mathrm{C}$ for the amplification of a product of about $400 \mathrm{bp}$. For the second pair of primers, an identical protocol was applied except that the annealing temperature was of $58^{\circ} \mathrm{C}$ and the elongation time at $72{ }^{\circ} \mathrm{C}$ was of $1 \mathrm{~min} 30$, and the product was around $950 \mathrm{bp}$ (1400 with the intron).

Sequencing: The PCR products where purified with the NucleoFast ${ }^{\mathbb{R}} 96$ PCR Clean Up kit from Macherey-Nagel (Düren, Germany) and sequenced at MWG Biotech (Martinsried, Germany). Products where sequenced using each time both forward and reverse primer, as well as the sequencing primer
Hyalo3R (CAATACAAGTGGCCCCAAC) which served to sequence the $5^{\prime}$ end of the second fragment (as described above).

Alignment and phylogenetic analysis: The SSU rRNA gene sequences obtained in this study where aligned manually using the BioEdit software (Hall 1999). We performed three phylogenetic analyses using three different datasets: (1) A first analysis including 38 sequences from the taxon Tubulina including our Hyalospheniidae (450 sites out of 550 positions), rooted with the most basal members of the Tubulina, the group of Echinamoeba and Hartmannella vermiformis (Fahrni et al. 2003). (2) A second analysis including all relatively short branch forming Arcellinids (i.e. without Centropyxis laevigata and Heleopera sphagni), with 
Argynnia dentistoma and Heleopera rosea as outgroups (using 830 sites out of 1050 positions). (3) A third analysis restricted to "core Nebelas", using Apodera vas and Nebela lageniformis as outgroups. The number of unambiguously aligned positions that were used in this phylogenetic analysis was 948 sites out of a total of about 1050 (1500 with the intron). In all analyses, we performed a maximum likelihood analysis using the software PHYML_v 2.4.4 (Guindon and Gascuel 2003) using the $\mathrm{GTR}+\mathrm{I}+\Gamma$ model. The reliability of internal nodes was estimated by bootstrapping (1000 replicates). In addition, the resulting tree was compared to the one obtained by Bayesian analysis. These analyses were performed with the software MrBayes v. 3.1.2 (Huelsenbeck and Ronquist 2001). The model chosen here was the GTR model of substitution (Lanave et al. 1984; Rodriguez et al. 1990), the number of invariable sites being estimated, and a gamma-shaped distribution of variable sites with five rate categories. The values of alpha and the proportions of invariable sites, were respectively, 0.467 and 0.269 , for the general Tubulina tree, 0.170 and 0.816 for the short-branching arcellinids, and 0.744 and 0.705 for the "core Nebelas" tree. For Bayesian analyses, four simultaneous chains were run for $1,000,000$ generations, and 10,000 trees were sampled, and trees corresponding to the likelihood estimates previous to stabilization of the likelihood plot where discarded as burn-in: 500 were removed from the first analysis (general Tubulina) and 100 for the second and the third (short-branching arcellinids and "core Nebelas"). Posterior probabilities at all nodes were estimated from the remaining trees.

\section{Acknowledgements}

This work was funded by Swiss NSF project no. 205321-109709/1 and EU project RECIPE. RECIPE was partly supported by the European Commission, Directorate I, under the programme "Energy, Environment and Sustainable Development" (no. EVK2-2002-00269) and partly, for the Swiss partners, by the State Secretariat for Education and Research, Switzerland. We thank Anita Maric for practical help in the lab and Fabienne Bobard and Marco Cantoni at the CIME (EPFL) for help with the SEM. We thank Mårten Flø Jørgensen (University of Copenhagen) and Sylvain Dubey (University of Lausanne) for the help with the phylogenetic analyses, Ralf Meisterfeld for useful comments on taxonomy, Jan Pawlowski and David Moreira for fruitful discussion on phylogeny, and also Hervé Philippe and an anonymous reviewer whose criticism substantially improved this manuscript. We also would like to acknowledge the following people for providing samples: Niek Gremmen (Data-Analyse Ecologie, $\mathrm{NL})$ for the samples from Marion Island, Sylvain Buhler for the sample from Peru, Martine Rebetez (WSL) for the mosses from Costa Rica, Nicolas Derungs for the cells of Porosia bigibbosa and Rebekka Arz (Macaulay Institute-UK) for the sample from Scotland.

\section{References}

Berney C, Pawlowski J (2006) A molecular time-scale for eukaryote evolution recalibrated with the continuous microfossil record. Proc R Soc Lond B 273: 1867-1872

Bobrov AA, Charman DJ, Warner BG (2002) Ecology of testate amoebae from oligotrophic peatlands: specific features of polytypic and polymorphic species. Biol Bull Russ Acad Sci 29: 605-617

Charman DJ (2001) Biostratigraphic and palaeoenvironmental applications of testate amoebae. Quart Sci Rev 20: 1753-1764

Charman DJ, Hendon D, Woodland WA (2000) The Identification of Testate Amoebae (Protozoa: Rhizopoda) in Peats. Quaternary Research Association, London

Chomczynski P, Sacchi N (1987) Single-step method of RNA isolation by acid guanidinium thiocyanate-phenol-chloroform extraction. Anal Biochem 162: 156-159

Deflandre G (1936) Etude monographique sur le genre Nebela Leidy. Ann Protistol 5: 201-286

Fahrni JF, Bolivar I, Berney C, Nassonova E, Smirnov A, Pawlowski J (2003) Phylogeny of lobose amoebae based on actin and small-subunit ribosomal RNA genes. Mol Biol Evol 20: $1881-1886$

Fiore-Donno A-M, Berney C, Pawlowski J, Baldauf SL (2005) Higher-order phylogeny of plasmodial slime molds (Myxogastria) based on elongation factor 1-A and small subunit rRNA gene sequences. J Eukaryot Microbiol 52: $201-210$

Gauthier-Lièvre L (1957) Additions aux Nebela d'Afrique. Bull Soc Nat Afr Nord 48: 494-525

Guindon S, Gascuel 0 (2003) A simple, fast, and accurate algorithm to estimate large phylogenies by maximum likelihood. Syst Biol 52: 696-704

Hall TA ed (1999) BioEdit: a user-friendly biological sequence alignment editor and analysis program for Windows 95/98/NT. Nucleic Acids Symp Ser 41: 95-98

Heinis F (1914) Die Moosfauna Columbiens: in: Voyage d'exploration scientifique en Colombie. Mem Soc Neuch Sci Nat 5: $675-730$

Huelsenbeck JP, Ronquist F (2001) MrBayes: Bayesian inference of phylogenetic trees. Bioinformatics 17: $754-755$

Johansen J, Haugen P (2001) A new nomenclature of group I introns in ribosomal DNA. RNA 7: 935-936

Jung W (1942) Illustrierte Thekamöben-Bestimmungstabellen. I. Die Systematik der Nebelinen. Arch Protistkd 95: $357-390$

Lanave C, Preparata G, Saccone C, Serio G (1984) A new method for calculating evolutionary substitution rates. J Mol Evol 20: 86-93

Lara E, Heger TJ, Mitchell EAD, Meisterfeld R, Ekelund F (2007) SSU rRNA reveals a sequential increase in shell complexity among the euglyphid testate amoebae (Rhizaria: Euglyphida). Protist 158: 229-237 
MacKinlay RB (1936) Observations on Nebela collaris Leidy (pro parte), a testate amoeba of moorland waters. Part 1. J R Microsc Soc 56: 307-325

Meisterfeld R (2000) Order Arcellinida Kent, 1880. In Lee JJ, Leedale GF, Bradbury P (eds) The Illustrated Guide to the Protozoa, Vol 2, 2nd edn. Society of Protozoologists, Lawrence, Kansas, USA, pp 827-860

Mitchell EAD, Meisterfeld R (2005) Taxonomic confusion blurs the debate on cosmopolitanism versus local endemism of free-living protists. Protist 156: 263-267

Mitchell EAD, Charman DJ, Warner BG (in press) Testate amoebae analysis in ecological and paleoecological studies of wetlands: past, present and future. Biodiv Conserv, doi:10.1007/s10531-007-9221-3

Mitchell EAD, Buttler AJ, Warner BG, Gobat JM (1999) Ecology of testate amoebae (Protozoa: Rhizopoda) in Sphagnum peatlands in the Jura mountains, Switzerland and France. Ecoscience 6: 565-576

Mitchell EAD, Buttler A, Grosvernier P, Rydin H, Albinsson C, Greenup AL, Heijmans MMPD, Hoosbeek MR, Saarinen T (2000) Relationships among testate amoebae (Protozoa), vegetation and water chemistry in five Sphagnum-dominated peatlands in Europe. New Phytol 145: 95-106

Nikolaev SI, Mitchell EAD, Petrov NB, Berney C, Fahrni J, Pawlowski J (2005) The testate lobose amoebae (order Arcellinida Kent, 1880) finally find their home within Amoebozoa. Protist 156: 191-202
Penard E (1902) Les Rhizopodes du bassin du Léman. Kündig, Genève

Porter SM, Knoll AH (2000) Testate amoebae in the Neoproterozoic Era: evidence from vase-shaped microfossils in the Chuar Group, Grand Canyon. Paleobiology 26: $360-385$

Porter SM, Meisterfeld R, Knoll AH (2003) Vase-shaped microfossils from the Neoproterozoic Chuar Group, Grand Canyon: a classification guided by modern testate amoebae. J Paleontol 77: 409

Rodriguez F, Oliver JL, Marin A, Medina JR (1990) The general stochastic model of nucleotide substitution. J Theor Biol 142: 485-501

Smith HG, Wilkinson DM (1987) Biogeography of testate rhizopods in the southern temperate and antarctic zones. Comité Nat. Français. Rech Antarctiques 58: 83-96

Todorov M (2002) Morphology, biometry and ecology of Nebela bigibbosa Penard, 1890 (Protozoa: Rhizopoda). Acta Protozool 41: 239-244

Van Oye P (1944) Au sujet de la distribution géographique des Rhizopodes. Biol Jahrb 11: 83-91

Vucetich MC (1974) Comentarios criticos sobre Argynnia Jung, 1942 (Rhizopoda, Testacea). Neotropica 20: 126-128

Warner BG (1987) Abundance and diversity of testate amoebae (Rhizopoda, Testacea) in Sphagnum peatlands in Southwestern Ontario, Canada. Arch Protistenkd 133: 173-189 